\title{
Sexual violence in armed conflicts: research progress and remaining gaps
}

\section{Carlo Koos}

Department of Politics and Public Administration, University of Konstanz, Germany

\begin{abstract}
Research on conflict-related sexual violence (CRSV) has grown rapidly over the last decade. This article consolidates existing social science research on CSRV according to two lines of inquiry: its causes and its consequences. Overall, research has considerably advanced our knowledge of the causes of CRSV, particularly in four aspects: purpose, context, individual motives and intra-group dynamics. However, there is a need to better understand the societal consequences of CRSV, in particular how it affects relations in families, and within and between communities. Overall there remains a shortage of empirical, in particular mixed-method, designs to produce research which is relevant for policymakers and practitioners.
\end{abstract}

\section{Introduction}

For a long time, sexual violence perpetrated by armed actors was assumed to be an inevitable by-effect of warfare. ${ }^{1}$ However, recent empirical studies have shown that sexual violence is not perpetrated in all conflict contexts. Sometimes there is even variation within the same conflict, where some armed actors commit sexual violence while others refrain from it. ${ }^{2}$ Such empirical findings are significant because they change our understanding and shed light on the complexities of conflict-related sexual violence (CRSV).

The purpose of this article is to critically review and consolidate the growing body of research on CRSV and identify gaps and questions which provide new research potential. The main part of this article is guided by two principal questions: (1) According to the scholarly literature on this topic, what are the causes of CRSV? And (2), again according to the relevant literature, what are its societal consequences? In the final part, I emphasise the limitation of existing research and point to avenues for future research agendas.

The answers to the causes and consequences of CRSV are important both for the scholarly debate on peace and conflict and for policymakers and practitioners. Research on the causes and consequences of CRSV is a key interest of peace and conflict research because the legacy of CRSV lasts long after wars have ended. For policymakers, knowing the causes of CRSV will ideally help them prevent it in the future. Furthermore, understanding the consequences will improve the provision of targeted and effective measures to help victims and communities recover. 


\section{Defining conflict-related sexual violence}

Before turning to the examination of the causes and consequences of CRSV, the concept itself requires some clarification. The two components of the term, conflict-related and sexual violence, imply that sexual violence in conflicts is different from sexual violence in peacetime. While sexual violence in conflict has similar roots to sexual violence during peacetime (for example, gender inequality, sociocultural views), it is aggravated by ethnic, religious, or ideological cleavages that increase the level of hatred and brutality. ${ }^{3}$ Cohen and Wood argue that the likelihood of gang rape is much higher in wartime (more than $70 \%$ ) compared to peacetime (2-27\%). CRSV is also associated with more brutal acts of rape, including in public spaces, with objects and torture. Often CRSV is associated with different goals including the humiliation of communities, the creation of terror and the spread of disease. ${ }^{4}$ These circumstances make wartime sexual violence distinct from that during times of peace.

Wood defines conflict-related sexual violence as 'sexual violence by armed organizations during armed conflict'. ${ }^{5}$ Armed organisations include both state forces (military, policy, government-sponsored militias) and non-state actors (rebels and militias). Sexual violence refers to '[ $r$ lape, sexual slavery, enforced prostitution, forced pregnancy, enforced sterilization, or any other form of sexual violence of comparable gravity' ${ }^{6}$

It is important to note that there are ongoing scholarly debates on the wider concept of CRSV apart from empiricists' definitions. Feminist scholars typically apply a broader perspective and thereby view the concept of CRSV as too focused on times of conflict. Scholars such as Eriksson Baaz, Stern, Kirby and Meger voice a growing concern that the international community capitalises on CRSV in a way that oversimplifies, even exploits, CRSV and neglects the larger sociocultural context in which sexual violence takes place. Feminist scholars argue that the focus on CRSV as being an extraordinary phenomenon ignores the fact that there is a continuum of gender-related hierarchies, inequalities, and violence not just during, but in particular before, conflict.' I will return to some feminist perspectives at the end of the next section.

\section{Causes of CRSV}

Most social science research is interested in determining the causes and functions of widespread sexual violence during civil conflicts. The longtime assumption that rape is an inevitable by-effect of warfare ${ }^{8}$ has been challenged by recent comparative empirical research, which has demonstrated variations in the prevalence of sexual violence across countries, across conflicts, and even across armed groups within the same conflict. ${ }^{9}$

How can we explain these differences in CRSV? There are four broad, not mutually exclusive, dimensions in the literature that aim to explain why CRSV is perpetrated.

\subsection{Purpose and strategic motives}

What does the existing scholarly literature tell us about the purpose of CRSV? The idea of using rape to punish groups of people based on certain characteristics (for instance, ethnic or religious identity, regional identities, assumed loyalties to other armed groups, etc.) is what distinguishes CRSV from everyday sexual violence perpetrated by spouses, relatives, acquaintances, or strangers. ${ }^{10}$ 
Much of this work argues that CRSV is a 'weapon of war' and is used strategically to terrorise, control, displace, and eliminate the civilian population by targeting female members. ${ }^{11}$ CRSV is viewed as a weapon of war as it demoralises the population and generates a slow genocide through the spread of HIV/AIDS. ${ }^{12}$ Along these lines, Brownmiller introduced the notion that wartime rape represents the communication between the conquering men and the defeated, via the medium of the women's bodies:

Defense of women has long been a hallmark of masculine pride, as possession of women has been a hallmark of masculine success. Rape by a conquering soldier destroys all remaining illusions of power and property for men of the defeated side. ${ }^{13}$

A few recent studies investigate CRSV against men. This form of sexual violence is commonly ascribed the goal of demoralising and emasculating men who belong to antagonised groups or who are disobedient civilians. ${ }^{14}$ There is little doubt that this form of sexual violence is intended to violate social norms and to humiliate people and communities.

One problem with the concept of rape as a strategic weapon of warfare is that there is often no clear evidence regarding its strategic and targeted use. Proving its strategic use would require information that CRSV has been part of a military strategy and that orders have been given to systematically commit sexual violence against specific groups of people (ethnic or religious groups, regions, etc.). Some cases leave little doubt about the strategic calculus of rape - for instance, Bosnia, Rwanda, Darfur, or Bangladesh. However, other cases with widespread CRSV, such as Liberia, Sierra Leona or Burundi, show patterns of indiscriminate rape. ${ }^{15}$ This is not to say that CRSV has not been ordered by military leaders in such cases, but without - at least anecdotal - evidence of such orders, most of these studies' conclusions are based merely on assumptions and interpretation. ${ }^{16}$

Relatedly, Thomas and Regan point out that from a military perspective mass rape can be a very counterproductive strategy because it nurtures feelings of revenge and may mobilise civilians against the perpetrating group. ${ }^{17}$ In eastern Congo, Elbert et al. report that explicit orders to rape were not the norm but rather the exception. What was more important appeared to be the absence of punishment in cases of rape. ${ }^{18}$

Feminist scholars take a critical stance towards the notion of rape as a weapon of war and how the international community responds to it. Eriksson Baaz and Stern are concerned about the reflexive use of the concept in all wartime contexts where sexual violence is prevalent, arguing that this sort of reductionism erases the significant empirical complexities of the respective sociocultural context. As a consequence, the international attention on and, related to that, resources for CRSV appear to have altered the incentives of victims, communities and humanitarian actors on the ground. ${ }^{19}$ For instance, Quillard observes that the provision of livestock through humanitarian organisations to CRSV victims in eastern Congo has led to an unprecedented self-identification as rape victims. ${ }^{20}$

Meger makes important observations about the way CRSV has been adopted by international actors. She detects a chain of processes involving the 'securitization', the objectification and the 'selling back' of sexual violence to those actors involved in armed conflict. One of Meger's main concerns is that through securitisation CRSV has been captured by international security actors, who consequently make decisions and policies regarding those who are directly affected by CRSV: victims, communities and perpetrators. ${ }^{21}$

Paul Kirby brings a different take to the securitisation of CRSV by arguing that on the one hand securitisation brings much-needed attention to neglected issues. On the other hand, securitisation gives power to security-related agencies, which may co-opt, dominate or 
redirect the ongoing discourse. Kirby disagrees with Meger's diagnosis about the extent to which CRSV has been securitised. Importantly, Kirby provides several examples that he interprets as evidence of the failing securitisation of CSRV, such as the United Nations (UN)'s peacekeeping troops' inability to stop CRSV in eastern Congo or the decreasing interest in the UK's Preventing Sexual Violence Initiative.22 The feminist debate on CRSV has a long history, which this article does not capture, but in general, feminist scholars agree that the 'weapon of war' discourse unduly narrows the focus on wartime sexual violence and disregards sexual violence and gender inequality in so-called peacetime. As an alternative, feminist scholars convincingly argue viewing sexual violence on a continuum before and after conflict alongside other forms of violence. ${ }^{23}$ By doing so, the underlying sources of gender-related power inequalities in the family, the society and the market can be identified and eventually addressed to prevent CRSV. In that sense, feminists view the perpetration of CRSV less as the control of the civilian population (i.e. as a weapon of war), and more as a brutalised form of continuing gender inequalities. ${ }^{24}$ These accounts echo Brownmiller's seminal work, which posits that men continually seek ways to dominate women and that the conditions of war provide the opportunity to use rape as a tool to exercise this urge..$^{25}$

The feminist debate clearly encourages scholars and practitioners to think about and work on altering the sociocultural conditions that contribute to gender inequalities and not just the symptom which is sexual violence during war. Empirical studies should therefore take the continuum of gender inequalities and the social context more into account.

\subsection{Contextual conditions and opportunity structures}

A large proportion of the existing academic literature agrees that the absence of the rule of law, impunity, weakened state institutions, and above all gender inequalities make sexual violence in the context of ethnic, religious, and ideological conflicts more likely. ${ }^{26}$ This context of lawlessness and impunity may set free a desire to commit rape in some men. ${ }^{27}$ In general, the contemporary literature largely agrees that the context of political instability and insecurity provides the necessary conditions for large-scale sexual violence. However, these conditions are not considered to be sufficient and are in fact common conditions for political violence and civil war more generally.

Wood makes the point that weak states do not automatically result in a breakdown of society and thereby unleash people to commit rape; rather, she holds, state failure will only provide a breeding ground for CRSV when societal norms break down in its aftermath - for instance, as a result of war, displacement, and crises. ${ }^{28}$ In her cross-national study of wartime rape in civil wars, Cohen finds partial support for a relationship between state collapse and CRSV; however, this is the case only for insurgent-perpetrated acts of mass rape and not state-perpetrated ones. ${ }^{29}$

Some scholars make the important observation that the circumstances and consequences of armed conflict'normalise' the phenomenon of CRSV. ${ }^{30} \mathrm{~A}$ similar undertone can be observed in Elbert et al's survey of ex-combatants in the DRC, in which respondents provide personal accounts of their experiences and crimes. ${ }^{31}$ Their matter-of-factness in talking about rape points to what is the core concern of feminist scholars and relates not only to CRSV but also to violence against women in general: gender inequalities and power imbalances that are deeply engrained in some societies, particularly patriarchal ones, and are passed on from 
generation to generation, thereby reproducing the scope conditions for the exploitation of women. ${ }^{32}$

In relation to this, what is generally assumed to be an important determinant of CRSV is the level of sexual violence before the war. Davies and True explicitly criticise recent empirical studies $^{33}$ on the causes of CRSV because these studies ignore the subtleties of gendered inequalities in the prewar period as explanatory variables for CRSVV. ${ }^{34}$ Therefore, they suggest the use of the Social Institutions and Gender Index (SIGI) in order to take multiple dimensions of gender relations into account. SIGI is a cross-country multidimensional index created by the Organisation for Economic Co-operation and Development (OECD) to monitor the development of gender rights as a potential predictor of CRSV. While the SIGI is sensitive to aspects such as the role of women in the family, legislation, resources and freedom, it remains a composite index which does not take into consideration variation across a country's territory, social classes or cultural groups.

Overall, the investigation of the contextual conditions leading to sexual violence in the quantitative literature on CRSV identifies conditions similar to those of civil wars: state collapse, the breakdown of law and order, and impunity. ${ }^{35}$ Future quantitative studies should include more sophisticated measures of gender equality or perceptions of gender relations. These are factors which feminist scholars consider to be of key importance to explain levels of CRSV.

\subsection{Individual motives}

According to the existing research, what are the individual drivers that make soldiers, militiamen, and civilians commit rape during conflict? Some accounts present the rape of the 'enemy's' women as the spoils of war - that is, as subjects of private pleasure for combatants. ${ }^{36}$ Others assert that the'soldier identity' that armies create - a mixture of masculinity, violence, and conquest - makes individual rank-and-file soldiers more likely to commit sexual assaults. ${ }^{37}$

Given the difficulty and cost of attaining the data, there is considerably less empirical research on the perpetrators' motives than on other aspects of CRSV. This makes the following contributions exceptionally noteworthy. Baaz and Stern present army soldiers'narratives on rape in the DRC and find a number of self-perceptions that contribute to explaining individuals' perpetration of CRSV. Soldiers distinguish between 'lust' rapes and 'evil' rapes. Lust rapes are described as serving the sexual needs of a man or soldier and are perceived as somewhat more ethically acceptable than evil rapes, which are described as an expression of hatred and anger. ${ }^{38}$ Both types appear to be driven by hypermasculinity and what is perceived as the male's right to have sex. Jacqui True notes that soldiers attribute their anger and frustration to poverty, lack of family, and the general and almost normalised climate of war and conflict. ${ }^{39}$ While the respondents admit that these personal views are causes, they blame the emergence of these views and attitudes on the conditions of war and conflict. Meger comes to similar conclusions, arguing that combatants' individual motivations to commit rape are associated with the social constructs of masculinity but must be understood in the context of the political economy of conflict. ${ }^{40}$

Kelly draws on qualitative interviews with members of the Mai Mai militia in eastern Congo and presents a slightly different perspective. ${ }^{41}$ The personal motivation for'evil' rape (as used 
above) appears to be less pronounced among Mai Mai members, as being perceived as a rapist could poison relationships with the population.

Psychological studies by Elbert and colleagues lend preliminary evidence to the'appetitive aggression' thesis which suggests that perpetrating extreme violence might be experienced as a rewarding, fascinating, and an addictive personal experience..$^{42}$ In another study, Elbert et al. show that about half of the respondents attributed CRSV to personal frustration and the absence of a wife with whom they could be sexually intimate. Also, the respondents reported raping civilians associated with enemy armed groups to avenge the rapes 'their' families and communities had experienced. ${ }^{43}$

The few existing studies on individuals' motives suggest that hypermasculinity, dire life conditions, and the lack of embeddedness into family and community life are key factors why some individuals commit rape in war. An under-examined aspect in extant research is the role of the family and the community as a provider of social stability and orientation as well as a monitoring authority of combatants' (mis)behaviour.

\subsection{Intragroup norms and dynamics}

Apart from the individual motives, there is a growing research strand that examines intragroup norms and dynamics, which play a substantial role in explaining the prevalence, extent, and brutality of CRSV. Two arguments are advanced. The first argument suggests that collective rape increases cohesion between members of armed groups. ${ }^{44}$ The idea is that jointly committing sexual violence creates bonds between perpetrators by generating collective feelings of power and superiority. ${ }^{45}$ Combatants in Elbert and colleagues' study confess that the most dangerous groups for women are made up of three to five combatants. They explain that in a group of this size, the dynamic allows individual combatants to exercise their full sexual aggression towards the victim. ${ }^{46}$ The privacy of small groups provides assurance that fellow rapists will keep quiet, even in extremely brutal cases. Larger groups have been reported to hinder such acts, as perpetrators may be more wary that fellow combatants with higher moral standards will report their behaviour. ${ }^{47}$

The second argument posits that the absence of penalties and norms prohibiting CRSV on the part of the group and its leadership make opportunistic (not strategic or tactical) sexual violence more likely. ${ }^{48}$ The accounts of demobilised combatants in the DRC illustrate that the absence of norms sanctioning CRSV allowed them to commit rape without fearing disciplinary consequences. In her paper on Peru and Guatemala, Leiby makes the case for a related point. According to her, information asymmetry - or in other words a loss of control over troops - is less likely in state-led military organisations and more likely in loose, poorly trained, and less hierarchical armed groups, which is assumed to increase the likelihood of $\mathrm{CRSV}^{49}{ }^{4}$ This claim is not unproblematic if one would compare the levels of army discipline in different contexts. Loose community militias may be under community surveillance (e.g. the Mai Mai militia mentioned above) while highly organised government armies of developed countries perpetrate horrific sexual violence (e.g. Abu Ghraib prison). Perhaps the more important aspect is that of ideology, discipline, accountability and the respect for basic human rights.

Both the pursuit of wartime rape for purposes of group cohesion and the lack of sanctioning norms are in principle in the hand of military leaders and the group's ideology, or the lack thereof. In that sense it would be a worthwhile road for future research to examine 
whether the ideological orientation of armed groups and its changes and norms are related to its gender views and - in turn - are associated with CRSV.

\section{Societal consequences of CRSV}

CRSV has severe implications for individuals, families, and societies, both in the short term and in the long term. ${ }^{50}$ These implications include the physiological harm to victims, psychological and mental trauma, and the effects on social relations within and beyond communities. Here I focus on the latter and review studies that examine the societal consequences of CRSV. Broadly speaking, three outcomes can be identified in the existing scholarly literature.

\subsection{Stigmatisation and rejection of victims}

It is widely assumed that women who were raped by (enemy) combatants will be stigmatised by families and shunned by their husbands. Women's sexuality and male honour are commonly viewed as intertwined in patriarchal societies. ${ }^{51}$ Skjelsbaek argues that the cultural values and taboos related to sexuality and the view of the female body as a symbol of a group's culture give patriarchal communities little room to integrate survivors. ${ }^{52}$

Stigmatisation of rape survivors can take different forms. To begin with, victims often blame themselves for what happened. In addition, families and communities often make the victim responsible for the sexual violence they experienced. Fear, uncertainty and rumours about HIV infections and rape-related pregnancies further increase the degree of stigmatisation and rejection of rape survivors by their spouses, relatives and communities..$^{53}$ In order to avoid rejection, survivors often remain silent about their ordeals in order to not lose their family.

The existing empirical evidence is more multifaceted than the assumptions about stigmatisation may suggest. There are several accounts of rejection. Kelly et al. report that $29 \%$ of raped women in their study in eastern Congo were rejected by their husbands and $6 \%$ of them were rejected by their communities. They conclude that widowhood, gang rape and rape-related pregnancy were associated with rejection. ${ }^{54}$ Sideris presents similar findings from Mozambique. Women who were raped and impregnated by the Renamo rebels faced rejection by their husbands. The children born from rape were not accepted in the community. ${ }^{55} \mathrm{~A}$ study from Rwanda reports that rape survivors were even compared to'prostitutes' by their community. ${ }^{56}$

Yet there are also several accounts of victims who were accepted and received support. Skjelsbaek presents narratives from Bosnian rape survivors who were not stigmatised but rather supported by their husbands, which contributed to their recovery. ${ }^{57}$ Utas presents interesting findings from Sierra Leone where he shows that traditional integration ceremonies have been critical in reducing the stigmatisation of rape survivors..$^{58}$

In sum, stigma can be understood as an underlying force which drives social rejection. While stigma is viewed as the common reaction to rape survivors, the empirical evidence shows that there are also cases - though limited in number - where victims are accepted and receive familial support. Research on the conditions of acceptance provide fruitful avenues for future research and could contribute to real change for victims, families and communities. 


\subsection{Damage to spousal, family and communal relations}

The institution of the family is a critical channel through which CRSV affects the wider community. Some men are seemingly torn between feelings of spousal support and the sociocultural expectation to reject a wife who has been raped. ${ }^{59}$ Trenholm et al. quote a traditional leader who expresses this discrepancy:

There are many husbands, many men [who] begin to understand the fate of the women, the fate of the children, but the society still takes the men hostage. ... It is the members of my family who come, the grandparents: How can you tolerate a woman like that, she will contaminate, bring sickness, she will bring you anxiety. ${ }^{60}$

The notion that the society takes the men hostage indicates the constraints that social norms place on individual male behaviour. The perceived pressure on men to reject their wives is also taken up by a participant of a focus group discussion in the eastern DRC: "The husband will be obliged to abandon the wife - abandon her so that he can go and get married with another wife, one who was not raped. Therefore, everything about marriage or family cohesion is scattered."61

Hagen and Yohani claim that CRSV victims have been associated so much with dishonour that not only the relations between them and their husbands but also those between them and their communities have been destroyed, with the result that they have been forced to move to places where nobody knows them. Others have chosen to lie to their partners and communities in order to prevent these conflicts and the resulting isolation. ${ }^{62}$ Apart from accounts of social exclusion, there is some evidence of the opposite. For instance, Utas and Stark present accounts from postwar Sierra Leone where traditional cleansing rituals were performed to re-introduce CRSV victims successfully into their home communities. ${ }^{63}$

While most of the accounts above are from African countries, Theidon shows how ambivalently men behaved in the aftermath of the Peruvian civil war. ${ }^{64}$ Although the rejection of raped women has been reported less in Peru, Theidon provides detailed information on how gendered power imbalances have affected the disclosure of war experiences. In her focus group discussions with both women and men, men repeatedly told the women to be quiet, even though it was the women who had endured the violence because the men had fled the conflict zone. The men's reasoning for leaving the women and children behind sounds absurd. One of them said: 'We decided the men should escape. They [the rebels] hated the men - we didn't think they'd do anything to the women.65

What is often overlooked is that the cover of war is at times used to pursue private objectives among civilians which may have little to do with the war's cleavages. ${ }^{66}$ In fact, some studies suggest that the percentage of combatant rape is much lower than civilian rape. ${ }^{67}$ When civilians commit sexual violence or are part of it during war, community cohesion and social trust suffers. A focus group participant in Kelly et al's study in the DRC demonstrates this point:

The war had a psychological impact on people; some betrayed their own family members. You know that this person did this or that to this person or he helped rebels to rape my mother. There will no longer be a trusting relationship between us. The war has brought up a poison phenomenon because there is no longer love among ourselves. ${ }^{68}$

The disruption of the social order is also intensified by massive displacement, which destroys social networks. Within the weakened social structures of (post)conflict societies, the perpetrators of violence - soldiers and combatants, both active and demobilised - often continue to terrorise civilians with impunity. ${ }^{69}$ 


\subsection{Collective coping, support and agency}

Some efforts have been undertaken to examine the conditions under which CRSV survivors take agency, the conditions under which family and community play a supportive role for survivors, and how gender relations change in the aftermath of conflict and CRSV. Research (unrelated to sexual violence) suggests that collective coping processes can be effective strategies for overcoming trauma. ${ }^{70}$ Indeed, recent microlevel studies find evidence that exposure to war-related trauma is related to post-traumatic growth, empathy-driven altruism and collective coping which in turn results in more prosocial behaviour. ${ }^{71}$ Could this partly apply also to individuals, families, and communities who have been exposed to CRSV? Kuwert and colleagues draw on interviews with CRSV survivors from the Second World War and find suggestive evidence for the posttraumatic growth thesis among CRSV survivors. $^{72}$

Mukamana and Brysiewicz present the personal accounts of CRSV survivors from the Rwandan genocide. In addition to the destructive consequences discussed earlier, they also observe that survivors had very positive experiences of joining survivors' associations. ${ }^{73}$ Members of such associations felt that the group partly replaced their families and their communities, lost during the genocide. Most importantly, the associations provided them with the means and group-esteem to take agency and fight the social stigma inflicted on rape survivors. For instance, they presented their experiences at community meetings, as one respondent explained: 'With the members of my association we make a campaign against the stigma on rape and HIV infection and it works. For example, the members of my church know that I am HIV-positive and they accept me. ${ }^{74}$

There is not that much quantitative evidence of collective coping in the social science literature on CRSV, but a recent psychological study finds evidence of its positive effect. A randomised controlled trial in the DRC shows that therapeutic group sessions for female survivors have significantly reduced symptoms of post-traumatic stress disorder. ${ }^{75}$

While a number of potential hypotheses can be derived from the literature discussed in this section, the empirical evidence used in most existing studies on the societal consequences of CRSV is relatively sparse. This limitation is true of both the sample sizes and the selection procedures by which respondents were chosen. Scholars often use convenience samples and rely on local partners (for instance, non-governmental organisations [NGOs], psychosocial centres) to establish contact between researcher and respondent. ${ }^{76}$ This selection method introduces a possible bias into the already small samples because all those survivors who did not, could not, or chose not to seek access to support facilities are excluded. Some of these excluded survivors may have found ways to deal with the consequences of CRSV more effectively than psychosocial centres can deliver, as for instance in the example of Sierra Leone mentioned above.

In that sense, more comprehensive field work and more quantitative data are required to capture these nuances and advance our understanding of the social consequences of CRSV. There is a need to consider counter-intuitive effects such as collective coping, post-traumatic growth and empathy-driven altruism within the spectrum of possible effects of CRSV. 


\section{Conclusion and future research}

The purpose of this article has been to review, condense and integrate existing theoretical and empirical studies on conflict-related sexual violence (CRSV) and to highlight new research avenues in this field. I have distinguished here between research on the causes and on the consequences of CRSV. Within the 'causes' literature, four aspects of CRSV have received attention. Most work deals with the question of which purposes CRSV serves. While empiricists suggest that it is intended to terrorise communities, feminist scholars hold the sociocultural gender-related power asymmetries responsible. Studies on the contextual conditions emphasise that the erosion of state institutions and the absence of the rule of law make CRSV more likely. Empirical work on the individual motives of fighters to commit CRSV have identified a distinction between 'lust' and 'evil' rapes, where the former serves to satisfy the sexual needs of combatants and the latter appears to be driven by bloodlust. ${ }^{77}$ Studies concerning intragroup norms and dynamics provide evidence that CRSV, in particular gang rape, serves the purpose of increasing bonding among combatants. ${ }^{78}$

While some seminal studies already exist, ${ }^{79}$ we need more empirical microlevel research from different contexts that helps us understand why some members of armed groups commit rape, particularly its most violent forms, and others do not. What explains these extreme forms of hatred against women in particular and civilians in general? Furthermore, how can gender inequalities and women's rights be effectively altered to decrease CRSV? And how can norms that prohibit sexual violence on the part of armed groups be created? Feminist international relations (IR) scholarship provides an established body of concepts, theories and comprehensive approaches ${ }^{80}$ which should be further integrated with qualitative and quantitative empirical approaches to produce promising scholarship.

Future research on the causes of CRSV will benefit from ambitious quantitative data collection efforts and mixed-method designs that overcome their limitations. ${ }^{81}$ Achieving the latter will entail, in particular, the collection of more disaggregated data. This can be done through the use of more targeted geocoded event data sets that build on reported cases of CRSV. Sources for such events could be drawn from international organisations working in this type of (post)conflict area - for instance, the UN and international and local humanitarian and human rights NGOs. Furthermore, future research on the relationship between gender inequality and CRSV can draw on the work of Davies and True as well as that of Butler and Jones. ${ }^{82}$

Empirical research on the societal consequences of CRSV is still in its infancy. In the existing literature, three consequences have been identified. First, survivors of CRSV are likely to experience social stigmatisation that results in social exclusion. ${ }^{83}$ Second, CRSV directly affects relations between survivors and their spouses, families and communities. Third, several studies focus on how CRSV survivors gain agency, receive support and cope with their trauma. ${ }^{84}$

All three of these aspects are important and of immense practical value in mitigating the destructive effects of CRSV, and therefore require further research. Additionally, far too little attention has been paid to compounding mechanisms that influence the effect of CRSV on social outcomes (for example, the circumstances of CRSV, the role of the community and support structures). Changes in the dynamics of gender relations as a result of conflict also remain - apart from a few exceptions ${ }^{85}$ - under-investigated.

The consequences of CRSV offer a broad range of important research opportunities. We must better understand how CRSV affects different aspects of social life, trust, and cohesion 
not only within but also beyond communities. The qualitative evidence discussed above offers important starting points to develop testable hypotheses. Are some communities resilient or better able to rebuild their collective social potential? ${ }^{86}$ If so, it would be important to learn how, in order to design policies and programmes that support those communities having difficulty in this regard. If some communities adopt a more supportive role in relation to CRSV survivors, does this have an effect on the survivors' recovery $?^{87}$ There are many more questions that would also be important to investigate.

The methodological sophistication in qualitative and, in particular, quantitative studies has generated important insights that are helpful for policymakers in addressing CRSV. For instance, Cohen's and Wood's comparative work on the determinants of wartime rape has shown that there is substantial variation in the prevalence of CRSV across countries, conflicts, and armed groups. ${ }^{88}$ This has challenged the previously held view that rape in war is inevitable. ${ }^{89}$ Such empirical findings have practical implications. If sexual violence is not an inevitable part of warfare, we can investigate what it is that prevents it and design policies and interventions that put that into practice.

Another empirical study of former combatants in the DRC challenges the notion of strategic and organised rape as a tool of warfare. Elbert et al. provide evidence that the order of sexual violence from superiors has been the exception rather than the norm. Instead, they show that the absence of sanctions for rape has been mentioned as a facilitating factor..$^{90}$ Importantly, such evidence-based insights relate to feminist scholars' scepticism regarding the'systematic weapon of war' thesis and rather point to underlying sociocultural conditions that affect gender inequality.

Our knowledge will continue to benefit from empirical studies, and particularly from the use of mixed-method research designs. Integrating quantitative and qualitative methods allows the researcher to exploit the strengths and balance the weaknesses of both methods, ideally resulting in greater generalisability of results while also maintaining empirical complexity. For the 'consequence' questions, the combination of qualitative field work and sensitive population-based surveys would be an appropriate method to better understand how communities deal with CRSV and how CRSV affects gender norms. Such approaches would contribute to deliver policy-relevant research which would improve strategies and programmes to reduce CRSV as well as to deliver targeted and improved support for CRSV victims.

\section{Disclosure statement}

No potential conflict of interest was reported by the author.

\section{Funding}

This work was supported by the Deutsche Forschungsgemeinschaft [grant number KO 5170/1-1]; the German Institute of Global and Area Studies.

\section{Acknowledgements}

I would like to thank Julia Strasheim, Alexander De Juan, Melissa Nelson, Matthias Basedau, Christian von Soest, two anonymous reviewers and the editorial team for invaluable comments. Furthermore, 
I am grateful to Monika Onken for her research assistance. Research for this article was supported by the German Research Council and the GIGA Institute Hamburg.

\section{Note on Contributor}

Carlo Koos is a senior research fellow at the Department of Politics and Public Administration at the University of Konstanz. His research deals with the political economy of conflict and development. His current research project focuses on the on the sociopolitical legacies of conflict-related sexual violence and is funded by the German Research Foundation (DFG). Methodologically he combines applied statistics and field research in South Sudan, Nigeria, Burundi and the DR Congo. He completed his PhD in political science at the University of Hamburg in 2015.

\section{Notes}

1. Brownmiller, Against Our Will; Seifert, "Second Front."

2. Cohen, "Explaining Rape during Civil War"; Leiby, "Wartime Sexual Violence"; Wood, "Variation in Sexual Violence."

3. Hagen and Yohani, "Nature and Psychosocial Consequences."

4. Cohen and Wood, "Is Sexual Violence during War Exceptional?".

5. Wood, "Conflict-Related Sexual Violence," 458.

6. International Criminal Court, cited in ibid., 459.

7. Eriksson Baaz and Stern, Sexual Violence as a Weapon of War?; Kirby, "How Is Rape a Weapon"; Meger, "Fetishization of Sexual Violence."

8. Brownmiller, Against Our Will.

9. Cohen, "Explaining Rape during Civil War"; Wood, "Armed Groups and Sexual Violence"; Wood, "Variation in Sexual Violence."

10. Hagen and Yohani, "Nature and Psychosocial Consequences"; Cohen and Wood, "Is Sexual Violence during War Exceptional?".

11. True, Political Economy of Violence.

12. Chowdhury and Lanier, "Rape and HIV."

13. Brownmiller, Against Our Will, 38.

14. Carpenter, "Recognizing Gender-Based Violence"; Cohen, "Female Combatants."

15. Human Security Report Project, Human Security Report 2012.

16. Leiby, "Wartime Sexual Violence in Guatemala and Peru," 448.

17. Thomas and Regan, "Rape in War."

18. Elbert et al., Sexual and Gender-Based Violence, 43.

19. Eriksson Baaz and Stern, Sexual Violence as a Weapon of War?

20. Quillard, "All Those Who Have Been Raped."

21. Meger, "Fetishization of Sexual Violence."

22. Kirby, "Security Fetish"; Kirby, "Ending Sexual Violence in Conflict."

23. Meger, "Fetishization of Sexual Violence"; Cockburn, "Gendered Dynamics of Armed Conflict"; Brownmiller, Against Our Will; Gottschall, "Explaining Wartime Rape”; Buss, "Rethinking 'Rape as a Weapon of War"'; Henry, "Theorizing Wartime Rape"; Eriksson Baaz and Stern, Sexual Violence as a Weapon of War?

24. Cockburn, "Gendered Dynamics of Armed Conflict."

25. Brownmiller, Against Our Will.

26. Meger, "Rape of the Congo"; Cohen, "Explaining Rape during Civil War"; Wood, "Armed Groups and Sexual Violence"; Leiby, "Wartime Sexual Violence"; Trenholm, Olsson, and Ahlberg, "Battles on Women's Bodies."

27. Brownmiller, Against Our Will.

28. Wood, "Armed Groups and Sexual Violence." 
29. Cohen, "Explaining Rape during Civil War."

30. Eriksson Baaz and Stern, "Why Do Soldiers Rape?"; Bastick, Grimm, and Kunz, Sexual Violence in Armed Conflict.

31. Elbert et al., Sexual and Gender-Based Violence.

32. Eriksson Baaz and Stern, "Why Do Soldiers Rape?"; Meger, "Fetishization of Sexual Violence"; Kirby, "How Is Rape a Weapon".

33. Cohen, "Explaining Rape during Civil War"; Wood, "Armed Groups and Sexual Violence”; Butler and Jones, "Establishing a Baseline."

34. Davies and True, "Reframing Conflict-Related Sexual and Gender-Based Violence."

35. Cohen, "Explaining Rape during Civil War"; Leiby, "Wartime Sexual Violence"; Green, "Uncovering Collective Rape."

36. Bidwell, Modern Warfare, 20.

37. Seifert, "Second Front"; Eriksson Baaz and Stern, "Why Do Soldiers Rape?"

38. Eriksson Baaz and Stern, "Why Do Soldiers Rape?"

39. True, Political Economy of Violence, 122.

40. Meger, "Rape of the Congo."

41. Kelly, Rape in War, 8.

42. Elbert, Weierstall, and Schauer, "Fascination Violence."

43. Elbert et al., Sexual and Gender-Based Violence, 40.

44. Cohen, "Explaining Rape during Civil War"; Bastick, Grimm, and Kunz, Sexual Violence in Armed Conflict; Wood, "Variation in Sexual Violence during War."

45. Cohen, "Female Combatants."

46. Elbert et al., Sexual and Gender-Based Violence, 46-7.

47. Eriksson Baaz and Stern, “Why Do Soldiers Rape?"; Green, “Uncovering Collective Rape”; Kelly, Rape in War.

48. Wood, "Variation in Sexual Violence"; Wood, "Armed Groups and Sexual Violence"; Meger, "Rape of the Congo"; Nordås and Rustad, "Sexual Exploitation and Abuse."

49. Leiby, "Wartime Sexual Violence in Guatemala and Peru."

50. Hagen and Yohani, "Nature and Psychosocial Consequences"; Kelly et al., "Hope for the Future Again"; Bastick, Grimm, and Kunz, Sexual Violence in Armed Conflict.

51. Seifert, "War and Rape: A Preliminary Analysis," 65; MacKinnon, "Rape, Genocide, and Women's Human Rights."

52. Skjelsbaek, "Victim and Survivor," 386.

53. Ohambe et al., Women's Bodies as a Battleground, 43.

54. Kelly et al., "Experiences of Female Survivors of Sexual Violence."

55. Sideris, "War, Gender and Culture."

56. Mukamana and Brysiewicz, "Lived Experience of Genocide," 382.

57. Skjelsbaek, "Victim and Survivor."

58. Utas, "Sexual Abuse Survivors."

59. Skjelsbaek, "Victim and Survivor."

60. Trenholm, Olsson, and Ahlberg, "Battles on Women's Bodies," 143.

61. Kelly et al., "Hope for the Future Again," 26.

62. Hagen and Yohani, "Nature and Psychosocial Consequences"; Skjelsbaek, "Victim and Survivor."

63. Utas, "Sexual Abuse Survivors"; Stark, "Cleansing the Wounds of War."

64. Theidon, "Gender in Transition."

65. Ibid., 460.

66. Butler, Gluch, and Mitchell, "Security Forces and Sexual Violence."

67. Peterman, Palermo, and Bredenkamp, "Estimates and Determinants of Sexual Violence"; Human Security Report Project, Human Security Report 2012; Meger, "Fetishization of Sexual Violence."

68. Kelly et al., "Hope for the Future Again," 29.

69. Kelly et al., "Hope for the Future Again."

70. Bowles, "Being Human."

71. Annan et al., "Civil War, Reintegration, and Gender."

72. Kuwert et al., "Long-Term Effects." 
73. Mukamana and Brysiewicz, "Lived Experience of Genocide."

74. Quoted in ibid., 382.

75. Bass et al., "Controlled Trial of Psychotherapy."

76. For instance, Denov, "Wartime Sexual Violence," relies on three interviews. Skjelsbaek, "Victim and Survivor," presents narratives from five CRSV survivors. Trenholm, "Battles on Women's Bodies," rely on interviews with 10 traditional leaders, and Mukamana and Brysiewicz, "The Lived Experience," study on the consequences of CRSV relies on seven interviews.

77. Eriksson Baaz and Stern, "Why Do Soldiers Rape?"

78. Cohen, "Explaining Rape during Civil War."

79. Ibid.; Wood, "Armed Groups and Sexual Violence"; Leiby, "Wartime Sexual Violence”; Eriksson Baaz and Stern, "Why Do Soldiers Rape?"; Elbert et al., Sexual and Gender-Based Violence.

80. Eriksson Baaz and Stern, "Why Do Soldiers Rape?"; Eriksson Baaz and Stern, Sexual Violence as a Weapon of War?; Meger, "Rape of the Congo"; Henry, "Theorizing Wartime Rape"; Davies and True, "Reframing Conflict-Related Sexual and Gender-Based Violence"; Kirby, "How Is Rape a Weapon of War?".

81. Cohen, "Explaining Rape during Civil War"; Leiby, "Wartime Sexual Violence”; Green, “Uncovering Collective Rape"; Theidon, "Gender in Transition"; Cohen and Nordås, "Sexual Violence in Armed Conflict."

82. Davies and True, "Reframing Conflict-Related Sexual and Gender-Based Violence"; Butler and Jones, "Establishing a Baseline."

83. Hagen and Yohani, "Nature and Psychosocial Consequences."

84. Mukamana and Brysiewicz, "Lived Experience of Genocide."

85. Davies and True, "Reframing Conflict-Related Sexual and Gender-Based Violence."

86. Utas, "Sexual Abuse Survivors."

87. Mukamana and Brysiewicz, "Lived Experience of Genocide."

88. Wood, "Armed Groups and Sexual Violence"; Wood, "Variation in Sexual Violence during War"; Cohen, "Explaining Rape during Civil War."

89. Brownmiller, Against Our Will.

90. Elbert et al., Sexual and Gender-Based Violence.

\section{Bibliography}

Annan, J., C. Blattman, D. Mazurana, and K. Carlson. "Civil War, Reintegration, and Gender in Northern Uganda." Journal of Conflict Resolution 55, no. 6 (December 1, 2011): 877-908. doi:10.1177/0022002711408013.

Bass, Judith K., Jeannie Annan, Sarah Mclvor Murray, Debra Kaysen, Shelly Griffiths, Talita Cetinoglu, Karin Wachter, Laura K. Murray, and Paul A. Bolton. “Controlled Trial of Psychotherapy for Congolese Survivors of Sexual Violence." New England Journal of Medicine 368, no. 23 (June 6, 2013): 2182-2191.

Bastick, Megan, Karin Grimm, and Rahel Kunz. Sexual Violence in Armed Conflict: Global Overview and Implications for the Security Sector. Geneva: Geneva Centre for the Democratic Control of Armed Forces, 2007.

Bidwell, Shelford. Modern Warfare: A Study of Men, Weapons and Theories. London: Penguin, 1973.

Boesten, Jelke. Sexual Violence During War and Peace: Gender, Power, and Post-Conflict Justice in Peru. New York: Palgrave Macmillan, 2014.

Bowles, Samuel."Being Human: Conflict: Altruism's Midwife." Nature 456, no. 7220 (November 20, 2008): 326-327.

Brownmiller, Susan. Against Our Will: Men, Women, and Rape. New York: Simon and Schuster, 1975. Buss, Doris E. "Rethinking 'Rape as a Weapon of War."' Feminist Legal Studies 17, no. 2 (July 17, 2009): 145-163. doi:10.1007/s10691-009-9118-5.

Butler, Christopher K., Tali Gluch, and Neil J. Mitchell. "Security Forces and Sexual Violence: A CrossNational Analysis of a Principal - Agent Argument." Journal of Peace Research 44, no. 6 (November 1, 2007): 669-687. doi:10.1177/0022343307082058. 
Butler, Christopher K., and Jessica L. Jones. "Establishing a Baseline: Can Peacetime Levels of Sexual Violence Predict Levels of Sexual Violence in Civil Conflict?" 2014. http://www.unm.edu/ ckbutler/ workingpapers/ButlerJones2014SVACWorkshop.pdf

Carpenter, Charli. "Recognizing Gender-Based Violence Against Civilian Men and Boys in Conflict Situations." Security Dialogue 37, no. 1 (March 1, 2006): 83-103. doi:10.1177/0967010606064139.

Chowdhury, Ishita, and Mark M. Lanier. "Rape and HIV as Methods of Waging War: Epidemiological Criminology's Response." Advances in Applied Sociology 02, no. 01 (2012): 47-52. doi:10.4236/ aasoci.2012.21006.

Christian, Mervyn, Octave Safari, Paul Ramazani, Gilbert Burnham, and Nancy Glass. "Sexual and Gender Based Violence against Men in the Democratic Republic of Congo: Effects on Survivors, Their Families and the Community." Medicine, Conflict and Survival 27, no. 4 (2011): 227-246.

Cockburn, Cynthia. "The Gendered Dynamics of Armed Conflict and Political Violence." In Victims, Perpetrators Or Actors?: Gender, Armed Conflict and Political Violence, edited by Caroline N. O. Moser and Fiona Clark. London, New York: Zed Books, 2001

Cohen, Dara Kay. “Explaining Rape during Civil War: Cross-National Evidence (1980-2009)." American Political Science Review 107, no. 3 (August 2013): 461-477. doi:10.1017/S0003055413000221.

Cohen, Dara Kay. “Female Combatants and the Perpetration of Violence: Wartime Rape in the Sierra Leone Civil War." World Politics 65, no. 3 (July 2013): 383-415. doi:10.1017/S0043887113000105.

Cohen, Dara Kay, and Ragnhild Nordås. "Sexual Violence in Armed Conflict Introducing the SVAC Dataset, 1989-2009."Journal of Peace Research 51, no. 3 (May 1, 2014):418-428. doi:10.1177/0022343314523028.

Cohen, Dara Kay, and Elisabeth Wood. "Is Sexual Violence during War Exceptional - or a Continuation of Everyday Violence?" ISQ Online, 2016. http://www.isanet.org/Publications/ISQ/Posts/ID/5239/Issexual-violence-during-war-exceptional-or-a-continuation-of-everyday-violence

Davies, Sara E., and Jacqui True. "Reframing Conflict-Related Sexual and Gender-Based Violence: Bringing Gender Analysis Back in." Security Dialogue 46, no. 6 (December 1, 2015): 495-512. doi:10.1177/0967010615601389.

Denov, Myriam. "Wartime Sexual Violence: Assessing a Human Security Response to War-Affected Girls in Sierra Leone." Security Dialogue 37, no. 3 (2006): 319-342. doi:10.1177/0967010615601389.

Elbert, Thomas, Harald Hinkel, Anna Mädl, Katharin Hermenau, Tobias Hecker, Maggie Schauer, Heike Riedke, Nina Winkler, and Philip Lancaster. Sexual and Gender-Based Violence in the Kivu Provinces of the Democratic Republic of Congo Insights from Former Combatants. Washington, D.C.: World Bank, 2013.

Elbert, Thomas, Roland Weierstall, and Maggie Schauer. "Fascination Violence: On Mind and Brain of Man Hunters." European Archives of Psychiatry and Clinical Neuroscience 260, no. Suppl 2 (November 2010): S100-105. doi:10.1007/s00406-010-0144-8.

Eriksson Baaz, Maria, and Maria Stern. Sexual Violence as a Weapon of War? Perceptions, Prescriptions, Problems in the Congo and Beyond. Nordiska Afrikainstitutet; Zed Books, 2013. http://www.divaportal.org/smash/record.jsf?pid=diva2:617148

Eriksson Baaz, Maria, and Maria Stern. "Why Do Soldiers Rape? Masculinity, Violence, and Sexuality in the Armed Forces in the Congo (DRC)." International Studies Quarterly 53, no. 2 (June 1, 2009): 495-518. doi:10.1111/j.1468-2478.2009.00543.x.

Gottschall, Jonathan. “Explaining Wartime Rape." Journal of Sex Research 41, no. 2 (May 2004): 129-136.

Green, Jennifer L. "Uncovering Collective Rape: A Comparative Study of Political Sexual Violence." International Journal of Sociology 34, no. 1 (April 1, 2004): 97-116.

Hagen, Kristen, and Sophie Yohani. "The Nature and Psychosocial Consequences of War Rape for Individuals and Communities." International Journal of Psychological Studies 2, no. 2 (2010): p14.

Hankins, Catherine A., Samuel R. Friedman, Tariq Zafar, and Steffanie A. Strathdee. "Transmission and Prevention of HIV and Sexually Transmitted Infections in War Settings: Implications for Current and Future Armed Conflicts." Aids 16, no. 17 (2002): 2245-2252.

Henry, Nicola. "Theorizing Wartime Rape Deconstructing Gender, Sexuality, and Violence." Gender \& Society 30, no. 1 (2016): 44-56. doi:10.1177/0891243215608780.

Human Security Report Project. "Human Security Report 2012: Sexual Violence, Education, and War: Beyond the Mainstream Narrative." Human Security Press. Vancouver: Human Security 
Press, 2012. http://hsrgroup.org/docs/Publications/HSR2012/2012HumanSecurityReport-Part1SexualViolenceEducationandWar.pdf

Kelly, Jocelyn, Theresa Betancourt, Dennis Mukwege, Robert Lipton, and Michael J. VanRooyen. "Experiences of Female Survivors of Sexual Violence in Eastern Democratic Republic of the Congo: A Mixed-Methods Study." Conflict and Health 5, no. 1 (2011): 1-8. doi:10.1186/1752-1505-5-25.

Kelly, Jocelyn. Rape in War: Motives of Militia in DRC. Washington, D.C.: United States Institute of Peace, 2010. http://www.peacewomen.org/assets/file/Resources/Government/vaw_ rapeinwarmotivesofmilitiaindrc_usip_2010.pdf

Kelly, Jocelyn, Michael VanRooyen, Justin Kabanga, Beth Maclin, and C. Mullin. "Hope for the Future Again: Tracing the Effects of Sexual Violence and Conflict on Families and Communities in Eastern Democratic Republic of the Congo." In Harvard Humanitarian Initiative. Cambridge, MA, 2011. http:// hhi.harvard.edu/sites/default/files/publications/hope-for-the-future-again.pdf.

Kirby, Paul. "Ending Sexual Violence in Conflict:The Preventing Sexual Violence Initiative and Its Critics." International Affairs 91, no. 3 (May 1, 2015): 457-472. doi:10.1111/1468-2346.12283.

Kirby, Paul. "How Is Rape a Weapon of War? Feminist International Relations, Modes of Critical Explanation and the Study of Wartime Sexual Violence." European Journal of International Relations 19, no. 4 (December 1, 2013): 797-821. doi:10.1177/1354066111427614.

Kirby, Paul. "The Security Fetish." ISQ Online, 2016. http://www.isanet.org/Publications/ISQ/Posts/ ID/5237/The-Security-Fetish

Kuwert, Philipp, Heide Glaesmer, Svenja Eichhorn, Elena Grundke, Robert H. Pietrzak, Harald J. Freyberger, and Thomas Klauer. "Long-Term Effects of Conflict-Related Sexual Violence Compared with Non-Sexual War Trauma in Female World War II Survivors: A Matched Pairs Study." Archives of Sexual Behavior 43, no. 6 (August 2014): 1059-1064. doi:10.1007/s10508-014-0272-8.

Leiby, Michele L. "Wartime Sexual Violence in Guatemala and Peru." International Studies Quarterly 53, no. 2 (2009): 445-468. doi:10.1111/j.1468-2478.2009.00541.x.

MacKinnon, Catharine A. "Rape, Genocide, and Women's Human Rights." Harvard Women's Law Journal 17 (1994): 5-16.

Meger, Sara. "Rape of the Congo: Understanding Sexual Violence in the Conflict in the Democratic Republic of Congo." Journal of Contemporary African Studies 28, no. 2 (April 2010): 119-135.

Meger, Sara. "The Fetishization of Sexual Violence in International Security." International Studies Quarterly 60, no. 1 (March 1, 2016): 149-159. doi:10.1093/isq/sqw003.

Mukamana, Donatilla, and Petra Brysiewicz. "The Lived Experience of Genocide Rape Survivors in Rwanda." Journal of Nursing Scholarship 40, no. 4 (2008): 379-384. doi:10.1111/j.1547-5069.2008.00253.x.

Nordås, Ragnhild, and Siri Rustad. "Sexual Exploitation and Abuse by Peacekeepers: Understanding Variation." International Interactions 39, no. 4 (2013): 511-534. doi:10.1080/03050629.2013.805128.

Ohambe, Marie Claire Omanyondo, Jean Berkmans Bahananga Muhigwa, Barnabé Mulyumba Wa Mamba, Réseau des Femmes pour un Développement Associatif, Réseau des Femmes pour la Défense des Droits et la Paix, and International Alert (Organization). Women's Bodies as a Battleground: Sexual Violence against Women and Girls during the War in the Democratic Republic of Congo: South Kivu (1996-2003). London: International Alert, 2005.

Peterman, Amber, Tia Palermo, and Caryn Bredenkamp. “Estimates and Determinants of Sexual Violence against Women in the Democratic Republic of Congo." American Journal of Public Health 101, no. 6 (2011): 1060-1067.

Quillard, Marion. "All Those Who Have Been Raped Raise Your Hand." De Groene Amsterdammer Special Edition edition, 2016. https://www.groene.nl/artikel/all-those-who-have-been-raped-raise-yourhand

Seifert, Ruth. "The Second Front: The Logic of Sexual Violence in Wars." Women's Studies International Forum 19, no. 1-2 (January 1996): 35-43. doi:10.1016/0277-5395(95)00078-X.

Seifert, Ruth. "War and Rape: A Preliminary Analysis." In Mass Rape: The War Against Women in BosniaHerzegovina, edited by Alexandra Stiglmayer, 54-72. Lincoln: U of Nebraska Press, 1994.

Sideris, Tina. "War, Gender and Culture: Mozambican Women Refugees." Social Science \& Medicine 56, no. 4 (2003): 713-724.

Skjelsbaek, Inger. "Sexual Violence and War: Mapping out a Complex Relationship." European Journal of International Relations 7, no. 2 (2001): 211-237. 
Skjelsbaek, Inger. "Victim and Survivor: Narrated Social Identities of Women Who Experienced Rape During the War in Bosnia-Herzegovina." Feminism \& Psychology 16, no. 4 (November 1, 2006): 373-403.

Stark, Lindsay. "Cleansing the Wounds of War: An Examination of Traditional Healing, Psychosocial Health and Reintegration in Sierra Leone." Intervention 4, no. 3 (2006): 206-218.

Theidon, Kimberly. "Gender in Transition: Common Sense, Women, and War." Journal of Human Rights 6, no. 4 (December 11, 2007): 453-478. doi:10.1080/14754830701693011.

Thomas, Dorothy Q., and Ralph Regan. "Rape in War: Challenging the Tradition of Impunity." SAIS Review 14, no. 1 (1994): 81-99. Journal Article.

Trenholm, J. E., P. Olsson, and B. M. Ahlberg. “Battles on Women's Bodies: War, Rape and Traumatisation in Eastern Democratic Republic of Congo." Global Public Health 6, no. 2 (March 2011): 139-152.

True, Jacqui. The Political Economy of Violence against Women. Oxford: Oxford University Press, 2012. Utas, Mats. "Sexual Abuse Survivors and the Complex of Traditional Healing. (G)local Prospects in the Aftermath of an African War." In Policy Dialogue. Uppsala, Sweden: The Nordic Africa Institute, 2009.

Wood, E. J. "Armed Groups and Sexual Violence: When Is Wartime Rape Rare?" Politics \& Society 37, no. 1 (March 1, 2009): 131-161. doi:10.1177/0032329208329755.

Wood, E. J. "Variation in Sexual Violence during War." Politics \& Society 34, no. 3 (September 1, 2006): 307-342. doi:10.1177/0032329206290426.

Wood, Elisabeth. "Conflict-Related Sexual Violence and the Policy Implications of Recent Research." International Review of the Red Cross 96, no. 894 (June 2014): 457-478. doi:10.1017/ S1816383115000077. 